Article

\title{
Impact of Irrigation Frequency and Planting Density on Bean's Morpho-Physiological and Productive Traits
}

\author{
Silas Alves Souza *, Joslanny Higino Vieira, Diego Bispo dos Santos Farias ${ }^{\circledR}$, \\ Gustavo Henrique da Silva and Catariny Cabral Aleman
}

Department of Agricultural Engineering, Federal University of Viçosa (UFV), Avenue Peter Henry Rolfs, Viçosa 36570-900, MG, Brazil; joslannyhigino@gmail.com (J.H.V.); diegotrust@gmail.com (D.B.d.S.F.); dasilva.h.gustavo@gmail.com (G.H.d.S.); catariny@ufv.br (C.C.A.)

* Correspondence: silas.a.souza@ufv.br

Received: 1 July 2020; Accepted: 31 August 2020; Published: 4 September 2020

\begin{abstract}
The correct irrigation frequency relies on the plant population density to increase yield and efficiency in water use. A field experiment was carried out in 2019 to study the effect of three irrigation frequencies, one (F1), four (F2), and eight (F3) days, and four planting densities, 20 (D1), 24 (D2), 28 (D3), and 30 (D4) plants per $\mathrm{m}^{2}$, on the variables: soil moisture, actual water consumption, growth, grain yield, and water productivity of beans (Phaseolus vulgaris L.). The soil water balance was calculated based on the soil moisture, which was measured by tensiometers. The irrigation was done by a drip tape. The variation in soil moisture was greatly influenced by irrigation frequencies and planting densities in F3. Plant growth was not affected by treatments. Irrigation frequencies and planting densities have deeply affected the biometric and chlorophyll synthesis traits of beans. The highest yields were found in the treatments F1D3 $\left(2968 \mathrm{~kg} \mathrm{ha}^{-1}\right)$, F1D4 (2997 kg ha-1), and F3D3 $\left(2946 \mathrm{~kg} \mathrm{ha}^{-1}\right)$. For water productivity, treatments with F1 irrigation frequency and the higher planting densities were more efficient in water use. Overall, the results are useful for technicians and farmers who work with irrigation management on beans.
\end{abstract}

Keywords: water stress; competition between plants; water productivity

\section{Introduction}

Over the years, climate change has greatly impacted agricultural production and the food supply, mainly due to harvesting losses and crop yield reduction [1,2]. Climate change has stimulated the intensive use of the available water resources and has endangered hydrological balance and sustainable agricultural production $[3,4]$. It is known that the relationship between water, agriculture, and climate is extremely significant. Thus, it is essential to seek techniques that minimize the impacts of water stress in a scenario with major challenges regarding inadequate water availability [5].

In Brazil, beans (Phaseolus vulgaris L.) are one of the main crops grown through the entire year and under different edaphoclimatic conditions [6,7]. The state of Minas Gerais is the second-largest producer in the country, with 554.039 tons produced per hectare [8]. The potential yield of beans can be impaired in conditions of water stress due to the lag in the processes of transpiration and absorption as a result of the low water availability [9-12].

Studies have shown that strategical water stress can improve crop yield in the field [13-15]. Therefore, knowing the right time to expose the crop to a water deficit is fundamental. The deficit irrigation strategy can be seen as a feasible and efficient technique to ensure greater crop yield, without putting in jeopardy their physiological processes and their final yield [16]. Little has been done to identify the impacts of the water deficit on the growth, yield, and chlorophyll characteristics of beans in 
the study region and therefore, this work provides important information for producers in the region or even for producers in other regions with the same characteristics as the present study.

Beyond the use of water deficit, another option to increase yield is the planting density technique. The increase in planting density should be carefully chosen so that intraspecific competition does not happen and it results in the best use of available resources for grain's growth and yield. Some studies have been carried out, in a range of 100,000 to 400,000 plants ha $^{-1}$, to verify the best plant density for beans $[17,18]$. However, the combination of water deficit and the planting density of common beans has been little studied and still lacks information, including the study of the physiological characteristics of the plant. In the present study, these questions were studied and the effects were justified by the results.

Studies comparing the use of water deficit associated with different planting densities are still scarce. There is still a need for information that identifies the best condition and the best technical strategy that ensures the highest crop yield under these conditions, or even the use of strategies that warrant savings in water, energy, and seeds, without reducing crop yield. In regions of water scarcity, as is the case in the study area, it is increasingly important to seek management techniques that aim to better use water resources to ensure productivity in a sustainable manner. Therefore, this work aims to verify the impact of irrigation frequency on the bean's morpho-physiological traits and water productivity under different planting densities and water deficit.

\section{Materials and Methods}

\subsection{Experimental Area}

The field experiment was carried out from May to August 2019 in the experimental area of Irrigation and Drainage, from the Department of Agricultural Engineering, Federal University of Viçosa (UFV), Viçosa-MG, Brazil, of which their geographical coordinates are $20^{\circ} 46^{\prime} 9^{\prime \prime} \mathrm{S}, 42^{\circ} 51^{\prime} 43^{\prime \prime} \mathrm{W}$, with an elevation of $651 \mathrm{~m}$ (Figure 1).

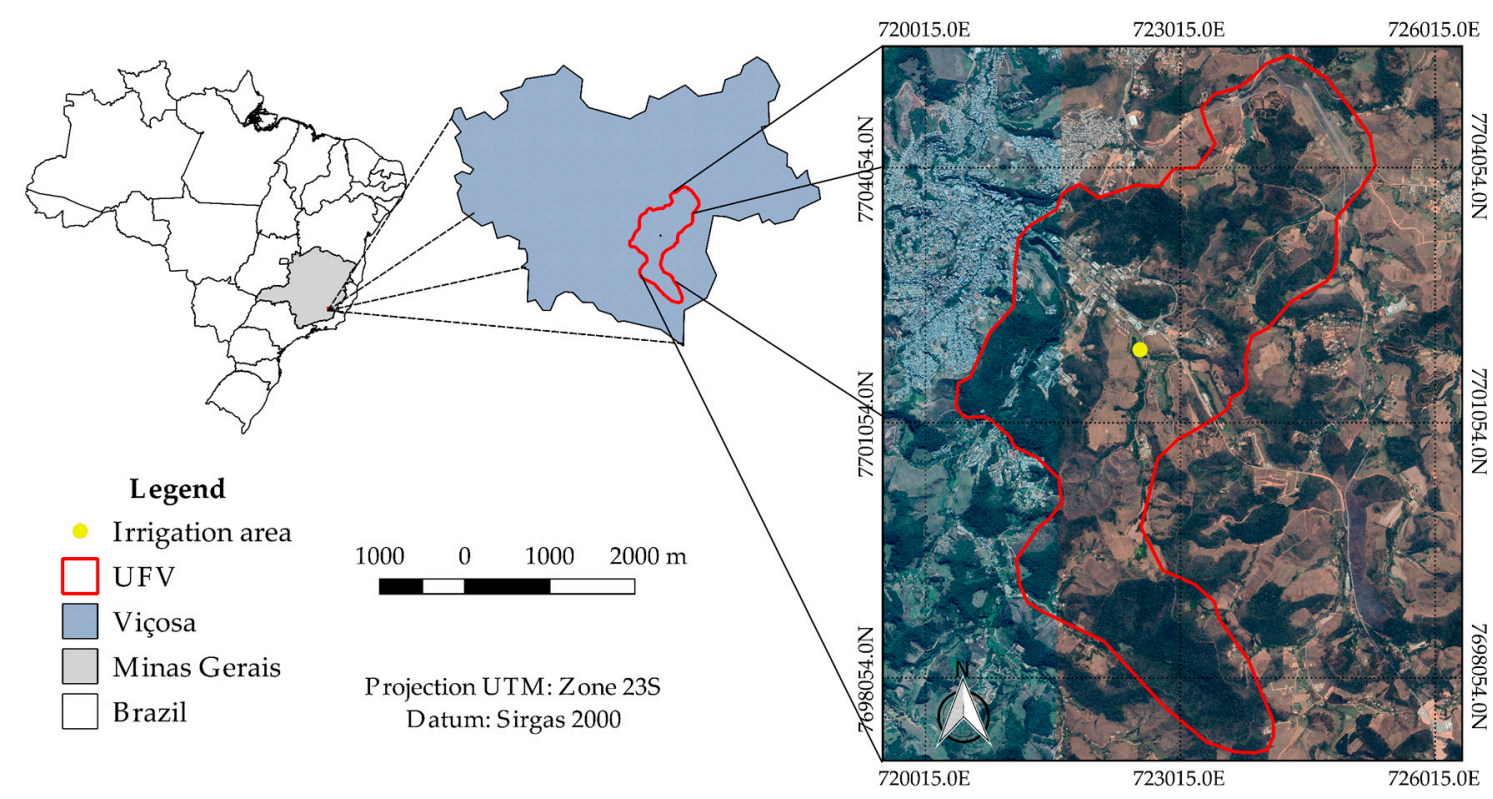

Figure 1. Location of the experimental area.

The region's climate according to Köppen's climate classification is "Cwa", tropical of altitude, with a rainy summer and dry winter [19]. During the experiment, the average air temperature was $18.8 \pm 2.4^{\circ} \mathrm{C}$, the average solar radiation was $13.6 \pm 3.6 \mathrm{MJ} \mathrm{m}^{-2}$, and the accumulated rainfall was $82 \mathrm{~mm}$ (Figure 2). 


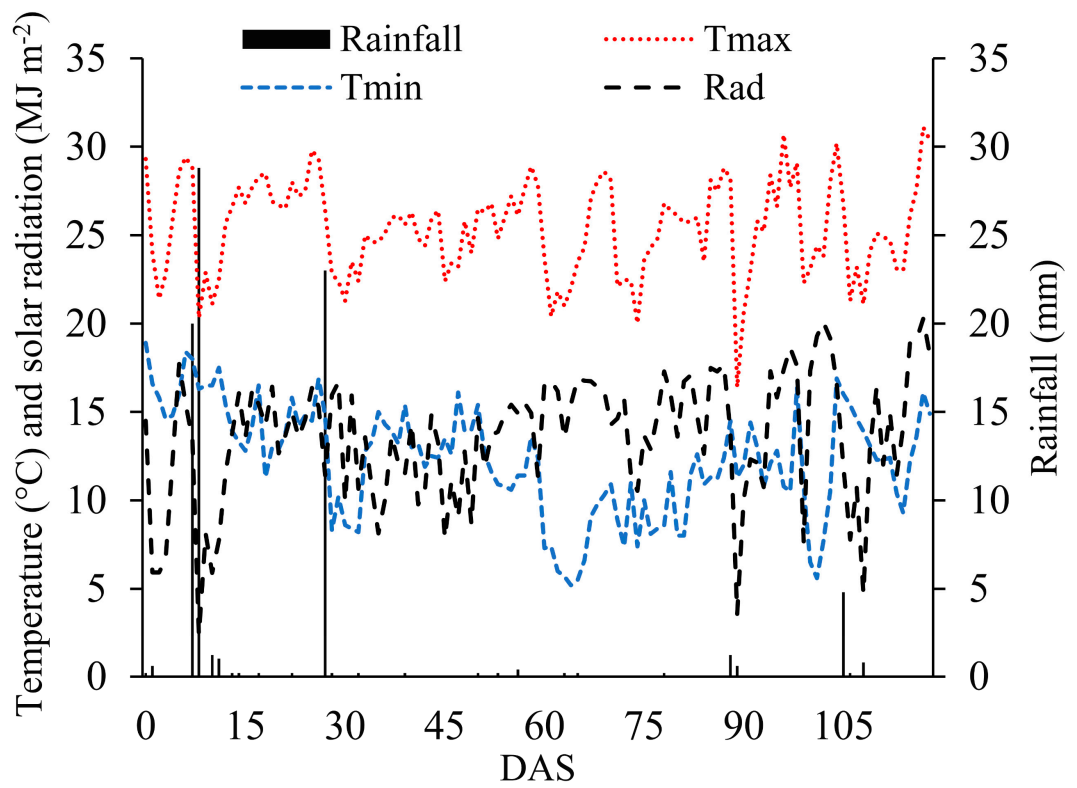

Figure 2. Daily values of solar radiation (Rad), maximum air temperature (Tmax), minimum air temperature (Tmin), and rainfall (Rainfall) during the experiment.

The soil of the experimental area is classified as Red-Yellow Argisol [20] and its chemical and physical characteristics are shown in Tables 1 and 2, respectively.

Table 1. Soil chemical characteristics of the experimental area.

\begin{tabular}{|c|c|c|c|c|c|c|c|c|c|}
\hline \multirow{2}{*}{$\begin{array}{l}\text { Soil Depth } \\
\text { (cm) }\end{array}$} & \multirow{2}{*}{$\frac{\mathrm{pH}}{\mathrm{H}_{2} \mathrm{O}}$} & $\mathrm{Ca}$ & $\mathrm{Mg}$ & $\mathrm{Al}$ & $\mathbf{P}$ & $\mathbf{K}$ & SB & CEC & \multirow{2}{*}{$\begin{array}{l}\mathrm{V} \\
\%\end{array}$} \\
\hline & & \multicolumn{3}{|c|}{$\mathrm{cmol} \mathrm{dm}^{-3}$} & \multicolumn{2}{|c|}{$\mathrm{mg} \mathrm{dm}^{-3}$} & \multicolumn{2}{|c|}{$\mathrm{cmol} \mathrm{dm^{-3 }}$} & \\
\hline $0-20$ & 6.0 & 2.3 & 1.0 & 0.0 & 21.2 & 135 & 3.7 & 6.1 & 60 \\
\hline $20-40$ & 5.62 & 2.84 & 0.65 & 0.00 & 14.2 & 35 & 3.58 & 6.48 & 55.3 \\
\hline
\end{tabular}

SB-sum of bases; CE—cation exchange capacity; V—base saturation.

Table 2. Soil physical characteristics of the experimental area.

\begin{tabular}{ccccc}
\hline Soil Depth $\mathbf{( c m )}$ & Texture & B.D. $\left(\mathrm{g} / \mathbf{c m}^{3}\right)$ & $\theta_{\mathrm{FC}}\left(\mathbf{c m}^{-\mathbf{3}} \mathbf{c m}^{-3}\right)$ & $\theta_{\mathbf{P W}}\left(\mathbf{c m}^{-3} \mathbf{c m}^{-3}\right)$ \\
\hline $0-20$ & Sandy clay & 1.30 & 0.46 & 0.25 \\
$20-40$ & Sandy clay & 1.28 & 0.51 & 0.26 \\
\hline
\end{tabular}

B.D. is the bulk density, $\theta_{\mathrm{FC}}$ is the field capacity $(-10 \mathrm{kPa}), \theta_{\mathrm{PW}}$ is the permanent wilting point $(-1500 \mathrm{kPa})$.

\subsection{Experimental Design}

The randomized block design in a split-plot $(3 \times 5)$ scheme with 5 replications was used. In the plot, the irrigation frequencies studied were: 1 (F1), 4 (F2), and 8 (F3) days. In the subplot, the plant densities studied were: 20 (D1), 24 (D2), 28 (D3), and 30 (D4) plants per $\mathrm{m}^{2}$.

Each plot was formed by three rows of plants spaced every $0.5 \mathrm{~m}, 1.5 \mathrm{~m}$ wide, and $2.0 \mathrm{~m}$ long, a total of $3.0 \mathrm{~m}^{2}$ for one experimental unit.

\subsection{Agronomic Practices}

The soil preparation was carried out with plowing and harrowing 15 days before sowing. The sowing of the common bean variety BRS Esteio was done on 7 May 2019, through mechanization, placing the seeds at a depth of $3 \mathrm{~cm}$. To ensure the proper stand and to avoid replanting, $50 \%$ more seeds were sown manually, using manual planters, in each treatment. At 18 days after sowing (DAS), the plant stand was adjusted for each treatment and the excess plants were thinned. 
Fertilization was carried out during sowing, using the formulated fertilizer 4-14-8 (N-P-K) at a dose of $250 \mathrm{~kg} \mathrm{ha}^{-1}$. After sowing, the fertilized ammonium sulfate $(20 \% \mathrm{~N})$ was applied at a dose of $10 \mathrm{~kg} \mathrm{ha}^{-1}$. The weeds were controlled by manual weeding. Pests and diseases were controlled through chemical methods. The harvest was carried out on 31 August 2019, 21 days after the last irrigation and 116 days after sowing.

\subsection{Irrigation System and Management}

A surface drip irrigation system was used. This comprised a $16 \mathrm{~mm}$ drip tape (Toro, model Aqua-Traxx, Plentirain, China) with emitters spaced every $30.5 \mathrm{~cm}$ and $1.50 \mathrm{~L} \mathrm{~h}^{-1}$ of flow, with an operating pressure of 1 bar. A drip tape was installed in each plant row. After sowing, $40 \mathrm{~mm}$ of water was applied by the irrigation system to ensure germination.

The irrigation depth applied in each treatment was determined based on the current soil moisture. For this, in each treatment, two tensiometers were installed in soil layers $0-20$ and $20-40 \mathrm{~cm}$. The readings of the tensiometers were taken daily, between 8:00 and 10:00 a.m. The frequency of the irrigations depended on each treatment (1, 4, or 8 days). The irrigation management period was 77 days, starting 18 days (25 May 2019) after sowing and ending on 10 August 2019, 15 days before harvest.

The tensiometers readings were converted into soil moisture through the soil water retention curve, obtained by the Richards chamber method. The Van Genuchten model [21] was adopted, considering the hydraulic characteristics of the soil shown in Table 2.

The irrigation depth was calculated for each treatment according to Equation (1).

$$
L I=\left(\left(\theta_{C C}-\theta_{a}\right) Z\right) / E f,
$$

where, $\mathrm{LI}$ is the irrigation depth, $\mathrm{mm} ; \theta_{\mathrm{CC}}$ is the volumetric soil moisture at field capacity, $\mathrm{m}^{3} \mathrm{~m}^{-3} ; \theta_{\mathrm{a}}$ is the volumetric current soil moisture before irrigation, $\mathrm{m}^{3} \mathrm{~m}^{-3} ; \mathrm{Z}$ is the crop's root system depth, $\mathrm{mm}$; and Ef is the efficiency of the irrigation system by field test, 0.98 .

\subsection{Water Consumption}

The actual water consumption during the bean cycle was calculated based on the soil water balance [22] through Equation (2).

$$
\mathrm{WC}=\mathrm{I}+\mathrm{P}+\mathrm{Cr}-\mathrm{Rf}-\mathrm{Dp} \pm \Delta \mathrm{S},
$$

where $\mathrm{WC}$ is the water consumption, $\mathrm{mm}$; $\mathrm{I}$ is the applied irrigation, $\mathrm{mm} ; \mathrm{P}$ is the rainfall, $\mathrm{mm} ; \mathrm{Cr}$ is the capillary rise, $\mathrm{mm}$; $\mathrm{Dp}$ is the percolation, $\mathrm{mm}$; $\mathrm{Rf}$ is the runoff, $\mathrm{mm} ; \Delta \mathrm{S}$ is the change in soil-water storage between sowing and harvesting, $\mathrm{mm}$.

In Equation (2), $\mathrm{Cr}$ was considered null because the water table was more than $15 \mathrm{~m}$ below the surface, $\mathrm{Rf}$ was also assumed to be insignificant because the experimental area is flat, and Dp was significant only when there was precipitation.

\subsection{Evaluated Parameters}

The plant height was measured weekly in three random plants from each plot. The evaluation of the chlorophyll a (Cfa) and b $(\mathrm{Cfb})$ levels in the leaves were obtained with the aid of a chlorophyll meter (model chlorofilog, Falker, BRA) in plants 67 DAS. After the grain filling phase (95 DAS), three plants were collected in each plot. Their stem, leaves, and pods were separated for the total and stratified quantification of fresh matter and percentage of aboveground dry matter, after drying at $65^{\circ} \mathrm{C}$ for $72 \mathrm{~h}$ in the heating chamber. Also, at 95 DAS, the height of the insertion of the first pod of the three plants collected was measured. At harvest, the weight of 1000 grains and yield (ton ha ${ }^{-1}$ ) were quantified. Finally, irrigation water productivity $\left(\right.$ ton $\mathrm{m}^{-3}$ ) was determined using the method of [23]. 


\subsection{Statistical Analysis}

The effects of the treatments were evaluated by variance analysis and when there was a significant difference, the means were separated by the Tukey test $(p<0.05)$ using the $\mathrm{R}$ software [24].

\section{Results}

\subsection{Changes in the Soil Moisture}

Variation in the average soil moisture, for the $40 \mathrm{~cm}$ layer, between irrigation events is shown in Figure 3 for each treatment. The irrigation frequency significantly affected the variation in soil moisture during the irrigation period. Irrigation started after adjusting the plant stand 18 days after sowing. The variation in soil moisture increased as the irrigation frequency decreased. At the irrigation frequency of one day (F1), the variation in soil moisture was 0.40 to $0.50 \mathrm{~cm}^{3} \mathrm{~cm}^{-3}$. In the irrigation frequency of four days (F2), the variation was 0.36 to $0.50 \mathrm{~cm}^{3} \mathrm{~cm}^{-3}$. In the irrigation frequency of eight days (F3), the variation was from 0.35 to $0.50 \mathrm{~cm}^{3} \mathrm{~cm}^{-3}$. Despite a similar variation between $\mathrm{F} 2$ and $\mathrm{F} 3$, the soil moisture remained close to the critical moisture for a longer time $\left(0.36 \mathrm{~cm}^{3} \mathrm{~cm}^{-3}\right)$ (Figure 3 ). Regarding the plant population, the variation in soil moisture was proportional to the plant density. The median soil moisture value decreased with the increase in planting density. In treatment F3, for half of the time, the soil moisture was below $0.40 \mathrm{~cm}^{3} \mathrm{~cm}^{-3}$ for planting density D4, $0.45 \mathrm{~cm}^{3} \mathrm{~cm}^{-3}$ for D3, $0.44 \mathrm{~cm}^{3} \mathrm{~cm}^{-3}$ for D2, and $0.46 \mathrm{~cm}^{3} \mathrm{~cm}^{-3}$ for D1. The effect of the four planting densities on the variation of soil moisture in the F1 and F2 treatments was quite similar (Figure 3).
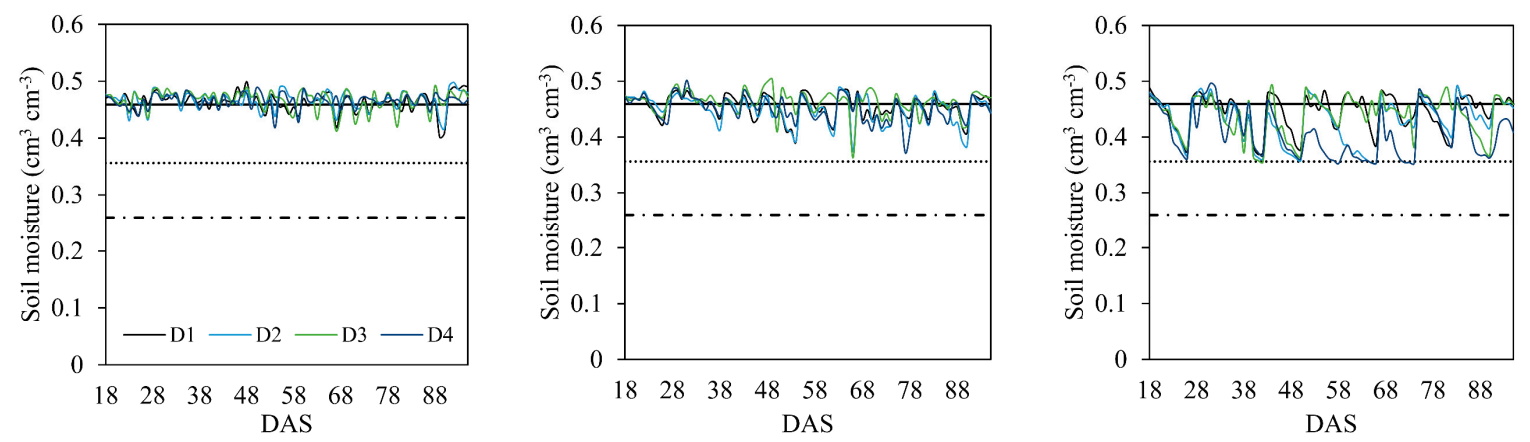

Figure 3. Variation of soil moisture in each treatment during the experiment. Continuous line (field capacity); Dotted line (management deficit); and Dashed line (permanent wilt point). Irrigation frequencies of one (F1), four (F2), and eight (F3) days. Planting densities of 20 (D1), 24 (D2), 28 (D3), and 30 (D4) plants per $\mathrm{m}^{2}$.

\subsection{Water Consumption}

The actual water consumption throughout the cycle can be seen in Figure 4. Overall, the bean's average water demand was higher in the irrigation frequency F2 $(131 \mathrm{~mm})$, followed by F3 $(122 \mathrm{~mm})$ and F1 (94 mm). The planting densities that most consumed water were D4 (157 mm) in F1, D2 (204 mm), D5 $(198 \mathrm{~mm})$ in F2, and D2 (194 mm) in F3. The bean's accumulated water consumption was lower than the accumulated reference evapotranspiration (ETo) $(212 \mathrm{~mm}$ ) during the experimental period (Figure 4). 


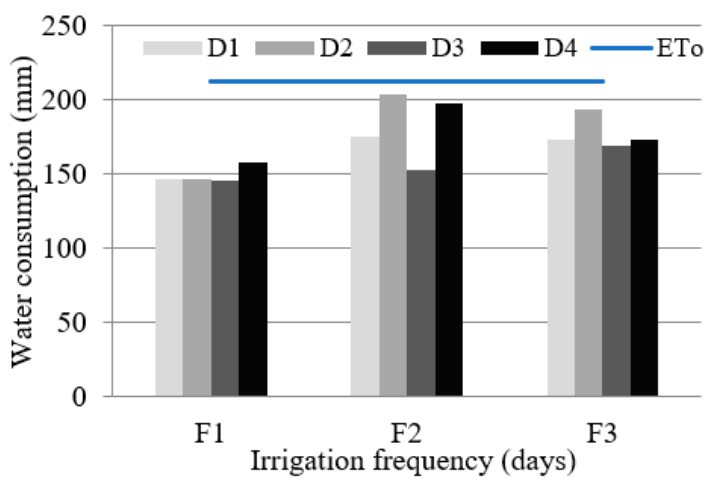

Figure 4. Bean's actual water consumption, in $\mathrm{mm}$, for each treatment. Irrigation frequencies of one (F1), four (F2), and eight (F3) days. Planting densities of 20 (D1), 24 (D2), 28 (D3), and 30 (D4) plants per $\mathrm{m}^{2}$.

\subsection{Morphological Traits}

\subsubsection{Plant Height}

Irrigation frequency and planting densities had little influence on plant height (Figure 5). Overall, the average variation coefficient was $4.7 \%$. The plant growth during the development cycle was very similar. In general, the maximum height of the plants was $60 \mathrm{~cm}$, verified in 70 DAS.
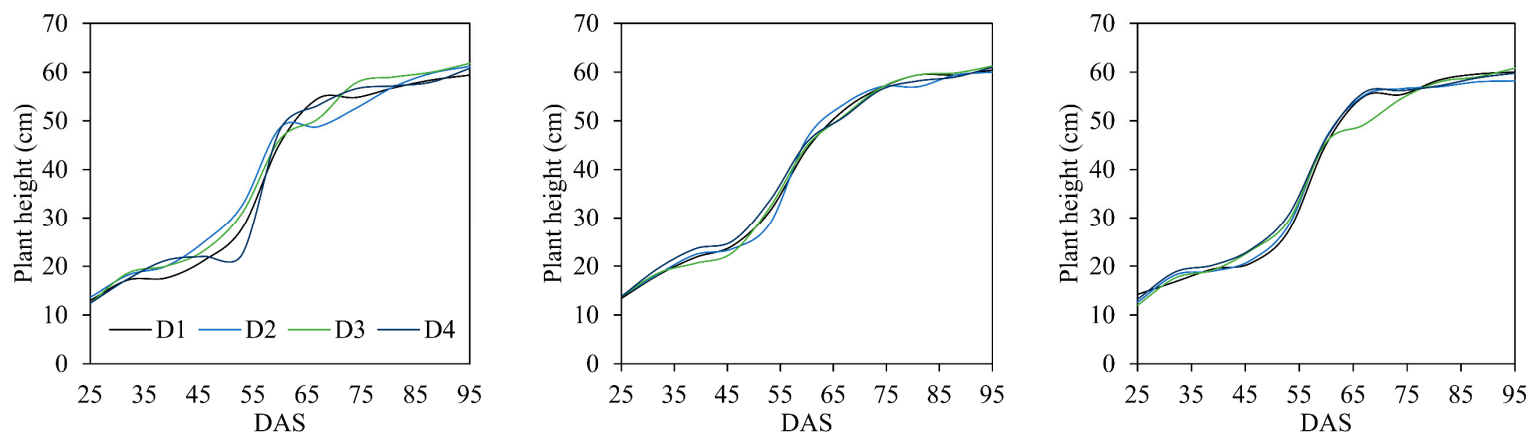

Figure 5. Plant height of the beans as a function of different irrigation frequencies and planting densities. Irrigation frequencies of one (F1), four (F2), and eight (F3) days. Planting densities of 20 (D1), 24 (D2), 28 (D3), and 30 (D4) plants per $\mathrm{m}^{2}$.

\subsubsection{Stem Diameter}

There was a significant interaction between the factors studied $(p<0.05)$ for the stem diameter variable (Table 3). Stem diameter values for planting densities at F1 and F2 frequency did not have a significant difference. However, only the irrigation frequency F3 had a difference between the stem diameter values. For this variable, the D4 density at the F3 frequency was $13.77 \%$ higher than the D1 density submitted to the same irrigation frequency. 
Table 3. Bean stem diameter as a function of different irrigation frequencies and plant densities.

\begin{tabular}{cccc}
\hline \multirow{2}{*}{ Planting Density } & \multicolumn{3}{c}{ Stem Diameter (cm) } \\
\cline { 2 - 4 } & $\mathbf{F 1}$ & $\mathbf{3}$ Irrigation Frequencies & F3 \\
\cline { 2 - 4 } & $7.0 \mathrm{Aa}$ & $6.3 \mathrm{ABa}$ & $6.1 \mathrm{Bb}$ \\
$\mathrm{D} 1$ & $6.6 \mathrm{Aa}$ & $6.3 \mathrm{Aa}$ & $6.9 \mathrm{Aab}$ \\
$\mathrm{D} 2$ & $6.5 \mathrm{Aa}$ & $6.3 \mathrm{Aa}$ & $6.2 \mathrm{Ab}$ \\
D3 & $7.2 \mathrm{Aa}$ & $6.0 \mathrm{Ba}$ & $7.1 \mathrm{Aa}$ \\
D4 & $p$-value \\
\hline ANOVA & 0.085 \\
Irrigation frequencies & 0.337 \\
Planting density & 0.017 \\
Interaction
\end{tabular}

Irrigation frequencies of one (F1), four (F2), and eight (F3) days. Planting densities of 20 (D1), 24 (D2), 28 (D3), and 30 (D4) plants per $\mathrm{m}^{2}$. Means followed by the same uppercase letter of the line and lowercase in the column do not differ from each other by the Tukey test ( $p$-value $>0.05)$.

\subsubsection{Chlorophyll Index in Leaves}

Planting densities did not affect the chlorophyll index in the leaves. However, the highest irrigation frequencies (F2 and F3) significantly increased the chlorophyll index " $a$ " in the leaves (Table 4).

Table 4. Chlorophyll index "a" (Cla) and " $b$ " (Clb) in the leaves, number of pods per plant (Pods), the height of insertion of the first pod (AI, cm), and the weight of 1000 seeds (1000S, grams) of the bean according to different irrigation frequencies and planting densities.

\begin{tabular}{cccccc}
\hline Treatments & Cla & Clb & Pods & AI & 1000S \\
\hline Plant density & & & & & \\
\hline D1 & 32.3 & 11.2 & 17.5 & 14.9 & $184 \mathrm{~b}$ \\
D2 & 32.2 & 11.0 & 17.5 & 16.0 & $185 \mathrm{ab}$ \\
D3 & 32.1 & 11.6 & 16.9 & 15.0 & $188 \mathrm{ab}$ \\
D4 & 31.1 & 10.2 & 16.2 & 15.5 & $192 \mathrm{a}$ \\
\hline Irrigation frequencies & & & & \\
\hline F1 & $30.5 \mathrm{~b}$ & 11.0 & $17.8 \mathrm{a}$ & 16.3 & 189 \\
F2 & $33.2 \mathrm{a}$ & 11.1 & $15.4 \mathrm{~b}$ & 14.6 & 186 \\
F3 & $32.1 \mathrm{a}$ & 10.9 & $18.0 \mathrm{a}$ & 15.2 & 186 \\
\hline ANOVA & & & $p$-value & & \\
\hline Plant density & 0.060 & 0.088 & 0.653 & 0.057 & 0.030 \\
Irrigation intervals & 0.001 & 0.595 & 0.026 & 0.094 & 0.468 \\
Interaction & 0.372 & 0.741 & 0.253 & 0.280 & 0.355 \\
\hline
\end{tabular}

Irrigation frequencies of one (F1), four (F2), and eight (F3) days. Planting densities of 20 (D1), 24 (D2), 28 (D3), and 30 (D4) plants per $\mathrm{m}^{2}$. Averages followed by the same lowercase letter in the column do not differ by the Tukey test $(p$-value $>0.05)$.

\subsubsection{Number of Pods per Plant}

Planting densities did not affect the number of pods per plant. However, the results numerically showed a decreasing trend in the number of pods with an increase in planting densities, which indicates competition. Still, the irrigation frequencies F1 and F3 showed a higher number of pods, approximately 18 pods per plant, than F2. The interaction between the two factors was not observed for this variable.

\subsubsection{Insertion of the First Pod}

The treatments did not influence the insertion height of the first pod. However, on average, treatments D2 $(16.0 \mathrm{~cm})$ and $\mathrm{F} 1(16.3 \mathrm{~cm})$ increased height by $6 \%$ and $9 \%$, respectively. The assessment 
of this variable although not directly related to the crop yield, is extremely important in the harvesting process since the greater the insertion height of the pod, the smaller the losses during harvest.

\subsubsection{Weight of 1000 Seeds}

The weight of 1000 seeds increased significantly with the increase in planting density (Table 4). The heaviest one was found in the planting density D4. The irrigation frequency did not impact this variable. However, on average, the F1 treatment had greater seed weight than F2 and F3.

\subsubsection{Number of Grains per Pod}

The number of grains per pod obtained a significant interaction $(p<0.05)$ between the two factors studied (Table 5). Statistically, the lowest number of grains per pod was only found in irrigation frequencies F1 in the density of plants D1 and for F2 in D4. Furthermore, it can be noted that the number of grains per pod was not negatively influenced by the decrease in the irrigation frequency during the bean crop cycle. Thus, it is verified that as well as the results obtained for the number of pods per plant under the studied conditions, crop yield will not change when the crop is irrigated at intervals up to 8 consecutive days.

Table 5. Number of grains per pod of bean crop according to different irrigation frequencies and planting densities.

\begin{tabular}{cccc}
\hline & \multicolumn{3}{c}{ Number of Grains per Pod } \\
\cline { 2 - 4 } Planting Density & F1 & Irrigation Frequencies \\
\cline { 2 - 4 } & $5.1 \mathrm{Bb}$ & $6.1 \mathrm{Aa}$ & F3 \\
\cline { 2 - 4 } D1 & $6.0 \mathrm{Aa}$ & $5.6 \mathrm{Aa}$ & $6.2 \mathrm{Aa}$ \\
$\mathrm{D} 2$ & $6.1 \mathrm{Aa}$ & $6.1 \mathrm{Aa}$ & $5.8 \mathrm{Aa}$ \\
$\mathrm{D} 3$ & $6.5 \mathrm{Aa}$ & $5.6 \mathrm{Ba}$ & $6.1 \mathrm{ABa}$ \\
D4 & & $p$-value \\
\hline ANOVA & 0.151 & \\
Irrigation frequencies & 0.351 & \\
Planting density & & $<0.001$ & \\
Interaction & &
\end{tabular}

Irrigation frequencies of one (F1), four (F2), and eight (F3) days. Planting densities of 20 (D1), 24 (D2), 28 (D3), and 30 (D4) plants per $\mathrm{m}^{2}$. Means followed by the same uppercase letter of the line and lowercase in the column do not differ from each other by the Tukey test ( $p$-value $>0.05)$.

\subsubsection{Biomass and Yield}

There was a significant interaction between the factors studied $(p<0.05)$ for the aboveground dry biomass (DB) parameter and grain yield (Table 6). The planting density D4 had higher DB than D1 for all irrigation frequencies in the proportion of $52 \%, 45 \%$, and $55 \%$ for $\mathrm{F} 1, \mathrm{~F} 2$, and F3, respectively. Overall, irrigation frequencies had little effect on the DB variable, except for F2 on D3. Also, in F3, D3 had a higher $\mathrm{DB}$ numerical value than $\mathrm{D} 4$. This indicates that a longer interval between irrigations can negatively affect the dry biomass yield in conditions of high planting density. 
Table 6. Aboveground dry biomass of plants and bean's grain yield as a function of different irrigation frequencies and planting densities.

\begin{tabular}{|c|c|c|c|c|c|c|}
\hline \multirow{3}{*}{$\begin{array}{l}\text { Planting } \\
\text { Density }\end{array}$} & \multicolumn{3}{|c|}{ Aboveground Dry Biomass (Mg ha ${ }^{-1}$ ) } & \multicolumn{3}{|c|}{ Yield (kg ha-1) } \\
\hline & \multicolumn{3}{|c|}{ Irrigation Frequencies } & \multicolumn{3}{|c|}{ Irrigation Frequencies } \\
\hline & F1 & F2 & F3 & F1 & F2 & F3 \\
\hline D1 & $6.18 \mathrm{Ab}$ & $5.63 \mathrm{Ab}$ & $5.00 \mathrm{Ab}$ & $2167 \mathrm{Ab}$ & $2554 \mathrm{Aa}$ & $2128 \mathrm{Abc}$ \\
\hline D2 & $7.13 \mathrm{Ab}$ & $5.90 \mathrm{Ab}$ & $7.46 \mathrm{Aa}$ & $2832 \mathrm{Aab}$ & $2697 \mathrm{Aa}$ & $1890 \mathrm{Bc}$ \\
\hline D3 & $8.13 \mathrm{ABab}$ & $6.44 \mathrm{Bab}$ & $9.47 \mathrm{Aa}$ & $2968 \mathrm{Aa}$ & $2601 \mathrm{Aa}$ & $2946 \mathrm{Aa}$ \\
\hline D4 & $9.40 \mathrm{Aa}$ & $8.18 \mathrm{Aa}$ & $7.73 \mathrm{Aa}$ & 2997 Аa & $2440 \mathrm{Ba}$ & $2519 \mathrm{Bab}$ \\
\hline ANOVA & \multicolumn{3}{|c|}{$p$-value } & \multicolumn{3}{|c|}{$p$-value } \\
\hline \multicolumn{2}{|c|}{ Irrigation frequencies } & \multicolumn{2}{|l|}{0.007} & \multicolumn{3}{|c|}{0.021} \\
\hline \multicolumn{2}{|c|}{ Planting density } & \multicolumn{2}{|l|}{$<0.001$} & \multicolumn{3}{|c|}{$<0.001$} \\
\hline \multicolumn{2}{|c|}{ Interaction } & \multicolumn{2}{|l|}{0.042} & \multicolumn{3}{|c|}{0.014} \\
\hline
\end{tabular}

Irrigation frequencies of one (F1), four (F2), and eight (F3) days. Planting densities of 20 (D1), 24 (D2), 28 (D3), and 30 (D4) plants per $\mathrm{m}^{2}$. Means followed by the same uppercase letter in the row and lowercase in the column do not differ by the Tukey test ( $p$-value $>0.05$ ).

For the yield variable, overall, the planting density D3 was the most productive for all irrigation frequencies (Table 6). The combinations F1D4 (2997 kg ha $\left.{ }^{-1}\right)$, F1D3 (2968 kg ha-1), and F3D3 $\left(2946 \mathrm{~kg} \mathrm{ha}^{-1}\right)$ showed the highest yield.

\subsubsection{Irrigation Water Productivity}

The planting density D3 resulted in the highest water productivity (WP) for all irrigation frequencies (Table 7). Overall, the irrigation frequency F1 had higher WP than F2 and F3. The F1D3 combination $\left(2.03 \mathrm{~kg} \mathrm{~m}^{-3}\right)$ had the highest water productivity.

Table 7. Bean's water productivity as a function of different irrigation frequencies and planting densities.

\begin{tabular}{cccc}
\hline & \multicolumn{3}{c}{ Water Productivity $\left(\mathbf{k g ~ m}^{-3}\right)$} \\
\cline { 2 - 4 } Planting Density & \multicolumn{3}{c}{ Irrigation Frequencies } \\
\cline { 2 - 4 } & $\mathbf{F 1}$ & $\mathbf{F} 2$ & $\mathbf{F 3}$ \\
\cline { 2 - 4 } $\mathrm{D} 1$ & $1.65 \mathrm{Ab}$ & $1.39 \mathrm{Bb}$ & $1.36 \mathrm{Bb}$ \\
$\mathrm{D} 2$ & $1.75 \mathrm{Ab}$ & $1.26 \mathrm{Bb}$ & $1.02 \mathrm{Cc}$ \\
$\mathrm{D} 3$ & $2.03 \mathrm{Aa}$ & $1.76 \mathrm{Ba}$ & $1.74 \mathrm{Ba}$ \\
$\mathrm{D} 4$ & $1.91 \mathrm{Aab}$ & $1.29 \mathrm{Bb}$ & $1.46 \mathrm{Bb}$ \\
\hline ANOVA & $p$-value \\
Irrigation frequencies & $<0.001$ \\
Planting density & $<0.001$ \\
Interaction & 0.010 \\
\end{tabular}

Irrigation frequencies of one (F1), four (F2), and eight (F3) days. Planting densities of 20 (D1), 24 (D2), 28 (D3), and 30 (D4) plants per $\mathrm{m}^{2}$. Means followed by the same uppercase letter of the line and lowercase in the column do not differ from each other by the Tukey test $(p$-value $>0.05)$.

\section{Discussion}

The irrigation frequency changed the temporal distribution of soil moisture. Increasing the irrigation frequency decreased the fluctuations in soil moisture and it remained closer to the field capacity moisture. However, decreasing the irrigation frequency causes greater fluctuations in soil moisture, which can reach higher levels of matrix tension, as verified in the present study. Soil's water depletion associated with a higher planting density can cause water stress and negatively impact biomass production and yield as observed in this study. 
A suitable irrigation frequency for different planting densities can increase yield and reduce water consumption. In a corn crop, reducing the irrigation interval to 6 days increased productivity [22]. Corn yield is severely impaired by the increase in planting density in conditions of low water availability [25]. For tomato crops, increasing the irrigation intervals from 1 to 7 days increased the efficiency of carboxylation and the photosynthesis rate, which increased yield by $35 \%$ [25]. The irrigation frequency as well as the amount of water must be adequate for each planting density. Furthermore, the right irrigation frequency depends on edaphoclimatic parameters and the hydraulic characteristics of the irrigation system.

Irrigation frequency and planting density significantly influence the biometric and physiological traits of plants [26] and the grain's quality [25]. Usually, water deficit greatly affects the biometric traits of beans [12]. With mechanized harvesting, the traits related to the architecture of the plants are essential to reduce losses. In this study, the plant height and the insertion height of the first pod were not affected by the treatments. Normally, the bean's biometric traits are more affected by row spacing than different planting densities [27]. Larger stem diameter is important as it supports the plant and prevents lodging, which is important for mechanized harvesting.

The use of planting density may have induced different interceptions of photosynthetically active radiation by the common bean, which had an influence on the grain yield of the crop. The use of density up to D4 generated a good use of light, water, and nutrients, reflected in grain yield. Therefore, by controlling the density of plants in the area, it is possible to obtain higher quality in the use of photosynthetically active radiation and return of the commercial product [28].

The chlorophyll index indicates water stress in plants [29] as this pigment is responsible for generating energy from water [30]. In this study, the lowest irrigation frequencies increased the chlorophyll index "a" but did not affect the chlorophyll index " $b$ ". This result may indicate that the bean increased the synthesis of chlorophyll "a" in the leaves to overcome the greatest fluctuations in soil moisture in treatments F2 and F3.

Limited water availability negatively affects the number of pods and consequently, the beans yield [29,31]. In general, treatments with higher yields had higher numbers of pods per plant and seeds per pod. F3 had higher numbers of pods per plant and seeds per pod than F2. Possibly, increasing the irrigation interval may have stimulated greater root growth followed by greater photosynthetic efficiency and carboxylation, which leads to a higher yield [26]. In legumes, the most sensitive stage to water stress is the reproductive stage, in which a lack of water during the flowering phase, pod formation, and grain filling can cause abscission of flowers and young pods [32]. However, in situations where there is a high density of plants and water stress, ethylene, a phytohormone present in the plant, can be influenced for greater production for a survival strategy, through the perpetuation of the species through the seed.

It was observed that as the planting density increased, the productivity also increased, however there was a reduction in productivity when the frequency of irrigation increased. It was observed that at the frequency of 8 days (F3), there was a 33.3\% reduction in productivity in the treatment with a planting density of 24 plants, in relation to the same planting density with an irrigation frequency of 1 day (F1). This can be justified because the low water levels in field conditions promote an increase in evapotranspiration and hinder the process of transforming light energy into chemical energy, which leads to reduced yield since the plant cannot successfully perform its photosynthesis cycle [33,34].

Water productivity (WP) indicates harvest yield per unit of water consumed by the crop [35]. WP was the highest for F1 irrigation frequency and higher planting densities. The decrease in water consumption was possibly due to the reduction of the soil evaporation component. Soil evaporation can, on average, account for $30 \%$ of total water consumption [36]. Probably, the higher production of dry biomass may have favored the canopy's bigger soil coverage, confirming those results obtained by [37]. A bigger development of the plant canopy can increase aerodynamic resistance and intercept more solar radiation, which increases photosynthetic efficiency, yield [33], and reduces soil evaporation [38]. 


\section{Conclusions}

Plant height, number of pods, and insertion height of the first pod were not impacted by the treatments applied, but a significant difference was observed for the variables stem diameter, chlorophyll index in the leaves, weight of 1000 seeds, and number of grains per pod.

The biomass was significantly influenced by the treatments applied, with the highest biomass being observed in the treatment with a density of 30 plants, reaching $55 \%$ more biomass in the frequency of 8 days when the density of 20 plants in the same frequency was purchased.

In the frequency of 8 days, there was a reduction in productivity of $33.3 \%$ in the treatment with a planting density of 24 plants, in relation to the same planting density with an irrigation frequency of 1 day (F1).

The highest yields were found in the treatments F1D3 $\left(2968 \mathrm{~kg} \mathrm{ha}^{-1}\right)$, F1D4 $\left(2997 \mathrm{~kg} \mathrm{ha}^{-1}\right)$, and F3D3 (2946 kg ha $\left.{ }^{-1}\right)$. For water productivity, treatments with F1 irrigation frequency and higher planting densities were the most efficient in the use of water.

Author Contributions: Conceptualization, D.B.d.S.F., G.H.d.S., S.A.S., J.H.V., and C.C.A.; methodology, D.B.d.S.F., G.H.d.S., S.A.S., J.H.V., and C.C.A.; investigation, D.B.d.S.F., G.H.d.S., S.A.S., and J.H.V.; writing-original draft preparation, D.B.d.S.F., G.H.d.S., S.A.S., and J.H.V.; writing—-review and editing, D.B.d.S.F., G.H.d.S., S.A.S., J.H.V., and C.C.A.; supervision, C.C.A. All authors have read and agreed to the published version of the manuscript.

Funding: This research was financed in part by the Coordenação de Aperfeiçoamento de Pessoal de Nível Superior-Brasil (CAPES)—Finance Code 001 and with support from CNPq, Conselho Nacional de Desenvolvimento Científico e Tecnológico-Brasil.

Acknowledgments: The authors would like to thank the Federal University of Viçosa and the Department of Agricultural Engineering.

Conflicts of Interest: The authors declare no conflict of interest.

\section{References}

1. Bisbis, M.B.; Gruda, N.; Blanke, M. Potential impacts of climate change on vegetable production and product quality-A review. J. Clean. Prod. 2018, 170, 1602-1620. [CrossRef]

2. Bray, E.A.; Bailey-Serres, J.; Weretilnyk, E. Responses to abiotic stresses. In Biochemistry and Molecular Biology of Plants; Gruissem, W., Buchannan, B., Jones, R., Eds.; ASPP: Rockville, MD, USA, 2000; pp. 1158-1249.

3. Kendy, E.; Zhang, Y.; Liu, C.; Wang, J.; Steenhuis, T. Groundwater recharge from irrigated cropland in the North China Plain: Case study of Luancheng County, Hebei Province, 1949-2000. Hydrol. Process. 2004, 18, 2289-2302. [CrossRef]

4. Wang, G.; Zhang, J.; Liu, J.F.; He, R. Quantitative assessment for climate change and human activities impact on river runoff. China Water Resour. 2008, 2, 55-58.

5. Oelofse, A.; Van Averbeke, W. Nutritional Value and Water Use of African Leafy Vegetables for Improved Livelihoods; Water Research Commission: Pretoria, Africa, 2012; ISBN 978-1-4312-0323-9.

6. Silva, M.C.C.D.; Andreotti, M.; Costa, N.R.; Lima, C.G.D.R.; Pariz, C.M.; Silva, M.C.C.D.; Andreotti, M.; Costa, N.R.; Lima, C.G.D.R.; Pariz, C.M. Soil physical attributes and yield of winter common bean crop under a no-till system in the brazilian cerrado. Rev. Caatinga 2017, 30, 155-163. [CrossRef]

7. Simplício, S.F.; De Gonçalves, A.C.M.; Da Duarte, E.C.C.; Barbosa, W.M.C.; Da Rodrigues, J.P.C.S.; De Oliveira, B.S.; De Júnior, S.P.S. Características de crescimento e produção do feijão-caupi (Vigna unguiculata L. Walp.) sob aplicação de herbicidas. Agropecu. Téc. 2016, 37, 55-62. [CrossRef]

8. Embrapa Socioeconomia para Arroz e Feijão. Available online: http://www.cnpaf.embrapa.br/socioeconomia/ index.htm (accessed on 27 June 2020).

9. Fernandes, F.B.P.; De Lacerda, C.F.; De Andrade, E.M.; Neves, A.L.R.; De Sousa, C.H.C. Efeito de manejos do solo no déficit hídrico, trocas gasosas e rendimento do feijão-de-corda no semiárido. Revista Ciência Agronômica 2015, 46, 506-515.

10. De Mendes, R.M.S.; Távora, F.J.A.F.; Pitombeira, J.B.; Nogueira, R.J.M.C. Relações fonte-dreno em feijão-de-corda submetido à deficiência hídrica. Revista Ciência Agronômica 2007, 38, 95-103.

11. Santos, M.G.; Ribeiro, R.V.; Machado, E.C.; Pimentel, C. Photosynthetic parameters and leaf water potential of five common bean genotypes under mild water deficit. Biol. Plant. 2009, 53, 229-236. [CrossRef] 
12. Silva, D.M.R.; Santos, J.D.; Costa, R.N.; Lima, A.D.S.; Santos, S.A.; Santos Silva, L.D.S. Resposta do feijoeiro a lâminas de água aplicada em relação à evapotranspiração da cultura. Revista Agropecuária Técnica Areia 2017, 38, 71. [CrossRef]

13. Gençoğlan, C.; Altunbey, H.; Gençoğlan, S. Response of green bean (P. vulgaris L.) to subsurface drip irrigation and partial rootzone-drying irrigation. Agric. Water Manag. 2006, 84, 274-280. [CrossRef]

14. Hegab, A.S.A.; Fayed, M.T.B.; Hamada, M.M.A.; Abdrabbo, M.M.A. Productivity and irrigation requirements of faba-bean in North Delta of Egypt in relation to planting dates. Ann. Agric. Sci. 2014, 59, 185-193. [CrossRef]

15. Satriani, A.; Loperte, A.; Soldovieri, F. Integrated geophysical techniques for sustainable management of water resource. A case study of local dry bean versus commercial common bean cultivars. Agric. Water Manag. 2015, 162, 57-66. [CrossRef]

16. Du, T.; Kang, S.; Zhang, J.; Davies, W.J. Deficit irrigation and sustainable water-resource strategies in agriculture for China's food security. J. Exp. Bot. 2015, 66, 2253-2269. [CrossRef]

17. Boakye Boateng, A.; Wilson, G. Effect of Cowpea (Vigna unguiculata) Variety and Plant Spacing on Grain and Fodder Yield. Asian J. Adv. Agric. Res. 2019, 1-9. [CrossRef]

18. Kamara, A.Y.; Omoigui, L.O.; Kamai, N.; Ewansiha, S.U.; Ajeigbe, H.A. Improving cultivation of cowpea in West Africa. In Achieving Sustainable Cultivation of Grain Legumes Volume 2: Improving Cultivation of Particular Grain Legumes; Sivasankar, S., Bergvinson, D., Gaur, P.M., Agrawal, S.K., Beebe, S., Tamò, M., Eds.; Burleigh Dodds Science Publishing: Sawston, UK, 2018; pp. 1-18. ISBN 978-1-78676-140-8.

19. Alvares, C.A.; Stape, J.L.; Sentelhas, P.C.; De Moraes Gonçalves, J.L.; Sparovek, G. Köppen's climate classification map for Brazil. Meteorologische Zeitschrift 2013, 22, 711-728. [CrossRef]

20. Dos Santos, H.G.; Jacomine, P.K.T.; Dos Anjos, L.H.C.; De Oliveira, V.Á.; Lumbreras, J.F.; Coelho, M.R.; De Almeida, J.A.; De Filho, J.C.A.; De Oliveira, J.B.; Cunha, T.J.F. Sistema Brasileiro de Classificação de Solos, 5th ed.; Embrapa: Brasília, Brazil, 2018; ISBN 978-85-7035-800-4.

21. Van Genuchten, M.T. A closed form equation for predicting the hydraulic conductivity of unsaturated soils. Soil Sci. Soc. Am. J. 1980, 44, 892-898. [CrossRef]

22. Zhang, G.; Shen, D.; Ming, B.; Xie, R.; Jin, X.; Liu, C.; Hou, P.; Xue, J.; Chen, J.; Zhang, W.; et al. Using irrigation intervals to optimize water-use efficiency and maize yield in Xinjiang, northwest China. Crop. J. 2019, 7, 322-334. [CrossRef]

23. Payero, J.O.; Tarkalson, D.D.; Irmak, S.; Davison, D.; Petersen, J.L. Effect of timing of a deficit-irrigation allocation on corn evapotranspiration, yield, water use efficiency and dry mass. Agric. Water Manag. 2009, 96, 1387-1397. [CrossRef]

24. R Core Team. R: A Language and Environment for Statistical Computing; R Foundation for Statistical Computing: Vienna, Austria, 2020.

25. El-Hendawy, S.E.; El-Lattief, E.A.A.; Ahmed, M.S.; Schmidhalter, U. Irrigation rate and plant density effects on yield and water use efficiency of drip-irrigated corn. Agric. Water Manag. 2008, 95, 836-844. [CrossRef]

26. Fara, S.J.; Delazari, F.T.; Gomes, R.S.; Araújo, W.L.; da Silva, D.J.H. Stomata opening and productiveness response of fresh market tomato under different irrigation intervals. Sci. Hortic. 2019, 255, 86-95. [CrossRef]

27. Horn, F.L.; Schuch, L.O.B.; Silveira, E.P.; Antunes, I.F.; Vieira, J.C.; Marchioro, G.; Medeiros, D.F.; Schwengber, J.E. Avaliação de espaçamentos e populações de plantas de feijão visando à colheita mecanizada direta. Pesquisa Agropecuária Brasileira 2000, 35, 41-46. [CrossRef]

28. Petter, F.A.; Silva, J.A.; Zuffo, A.M.; Andrade, F.R.; Pacheco, L.P.; Almeida, F.A. Elevada densidade de semeadura aumenta a produtividade da soja? Respostas da radiação fotossinteticamente ativa. Bragantia 2016, 75, 173-183. [CrossRef]

29. Vieira, G.H.S.; Mantovani, E.C.; Sediyama, G.C.; Delazari, F.T. Indicadores morfo-fisiológicos do estresse hídrico para a cultura da cana-de-açúcar em função de lâminas de irrigação. Biosci. J. 2014, 30, 65-75.

30. Nobel, P.S. Physicochemical and Environmental Plant. Physiology; Elsevier: Amsterdam, The Netherlands, 2009; ISBN 978-0-12-374143-1.

31. Chavoshi, S.; Nourmohammadi, G.; Madani, H.; Abad, H.H.S.; Fazel, M.A. Halt irrigation and red bean (Phaseolus vulgaris L.) cultivars responses. Int. J. Trop. Agric. 2016, 34, 2203-2211.

32. Saucedo, M.C.C.; Tellez, V.A.; Hernandes, A.D.; Alvarado, A.S.V.; Santos, G.G. Physiologial performance, yield and quality of dry bean seeds under drought stress. Interciencia 2009, 34, 748-754. 
33. Mir, R.R.; Zaman-Allah, M.; Sreenivasulu, N.; Trethowan, R.; Varshney, R.K. Ntegrated genomics, physiology and breeding approaches for improving drought tolerance in crops. Theor. Appl. Genet. 2012, 125, 625-645. [CrossRef] [PubMed]

34. Taiz, L.; Zeiger, E.; Moller, I.M.; Murphy, A. Fisiologia e Desenvolvimento Vegetal; Artmed: Porto Alegre, Brazil, 2017; Volume 6.

35. Pereira, L.S.; Oweis, T.; Zairi, A. Irrigation management under water scarcity. Agric. Water Manag. 2002, 57, 175-206. [CrossRef]

36. Allen, R.G.; Pereira, L.S.; Raes, D.; Smith, M. Crop Evapotranspiration-Guidelines for Computing Crop Water Requirements; FAO Irrigation and Drainage Paper No. 56; Food and Agriculture Organization of the United Nations: Rome, Italy, 1998; Volume 56.

37. Chen, Z.; Niu, Y.; Zhao, R.; Han, C.; Han, H.; Luo, H. The combination of limited irrigation and high plant density optimizes canopy structure and improves the water use efficiency of cotton. Agric. Water Manag. 2019, 218, 139-148. [CrossRef]

38. Yang, N.; Sun, Z.-X.; Feng, L.-S.; Zheng, M.-Z.; Chi, D.-C.; Meng, W.-Z.; Hou, Z.-Y.; Bai, W.; Li, K.-Y. Plastic Film Mulching for Water-Efficient Agricultural Applications and Degradable Films Materials Development Research. Mater. Manuf. Process. 2015, 30, 143-154. [CrossRef]

(C) 2020 by the authors. Licensee MDPI, Basel, Switzerland. This article is an open access article distributed under the terms and conditions of the Creative Commons Attribution (CC BY) license (http://creativecommons.org/licenses/by/4.0/). 